УДК 7.033.2...1

ББК $85.12 ; 63.3$ (0) 4

DOI:10.18688/aa155-2-24

Silvia Pedone

\title{
The Emperor Teophilos (829-842) between classicism and exoticism
}

In a conference devoted to the exploration of the longue durée of the Classic model, between Late-Antique and Early Modern art, guided by the idea of the enduring presence of the descent of Graeco-Roman artistic language within the later tradition, it seemed to me interesting to try to analyze, as for the history of Byzantine art, those aspects and moments which appear somewhat distant from "classical" tradition, thus also distancing myself from the no less enduring debates about the several forms of survival and renascence of ancient models in the passage of the Greek legacy from Byzantium to the Modern Age[28; 31; 37].

What I will rather attempt to probe here, though briefly, is the permeability of Classic artistic language in the age of the emperor Theophilos, a period which, at least according to the main historical sources, was oriented toward a different taste and was most influenced by exotic cultures, especially the Islamic one, which Byzantium, volens nolens, had to face for better or for worse.

Therefore, I would try to replace for the conventional polarization of "innovation" and "conservation" - or "exoticism" and "classicism" - a more "functionalist" dynamic model, which takes into account the specific, visual strategic purposes in the use of an artistic language or form, chosen for the reestablishment and the celebration of a political order, or to emphasize a break-point with the near past. From such a point of view, that of Theophilos seems a good case study to verify how classic heritage and exotic openness could coexist and be of service for one and the same political project [10;41].

According to some sources, the interest of Theophilos in islamicizing fashions is the output of his propensity in favour of Iconoclasm; an attitude shared with the syncellos John the Grammarian, who was his tutor and then Patriarch [24]. In fact, under Theophilos the struggle against the sacred images reached a new and last upsurge, before the final restoration of orthodoxy, after the death of the emperor, in 842. Through the lively account of Theophanes Continuatus, but also according to some passages of De Cerimoniis of Constantine VII Porphyrogenitus and other texts perhaps written thanks to the intercession of Theodora, the profile of the emperor Theophilos emerges as a complex and even a contradictory personality, example of justice, persecutor of iconoduli, curious intellectual, military chief and art lover, patron of new and lavish monumental enterprises, above all in Constantinople $[2 ; 11 ; 29 ; 33]$.

He devoted particular attention to the restoration of the city walls, resuming, from both an architectural and ideological point of view, the old Theodosian defensive system, by the creation of mighty towers on the land side - especially in the $14^{\text {th }}$ region - and toward the Sea of Marmara. Long inscriptions, still in situ, celebrate the memory of the Basileus and his 

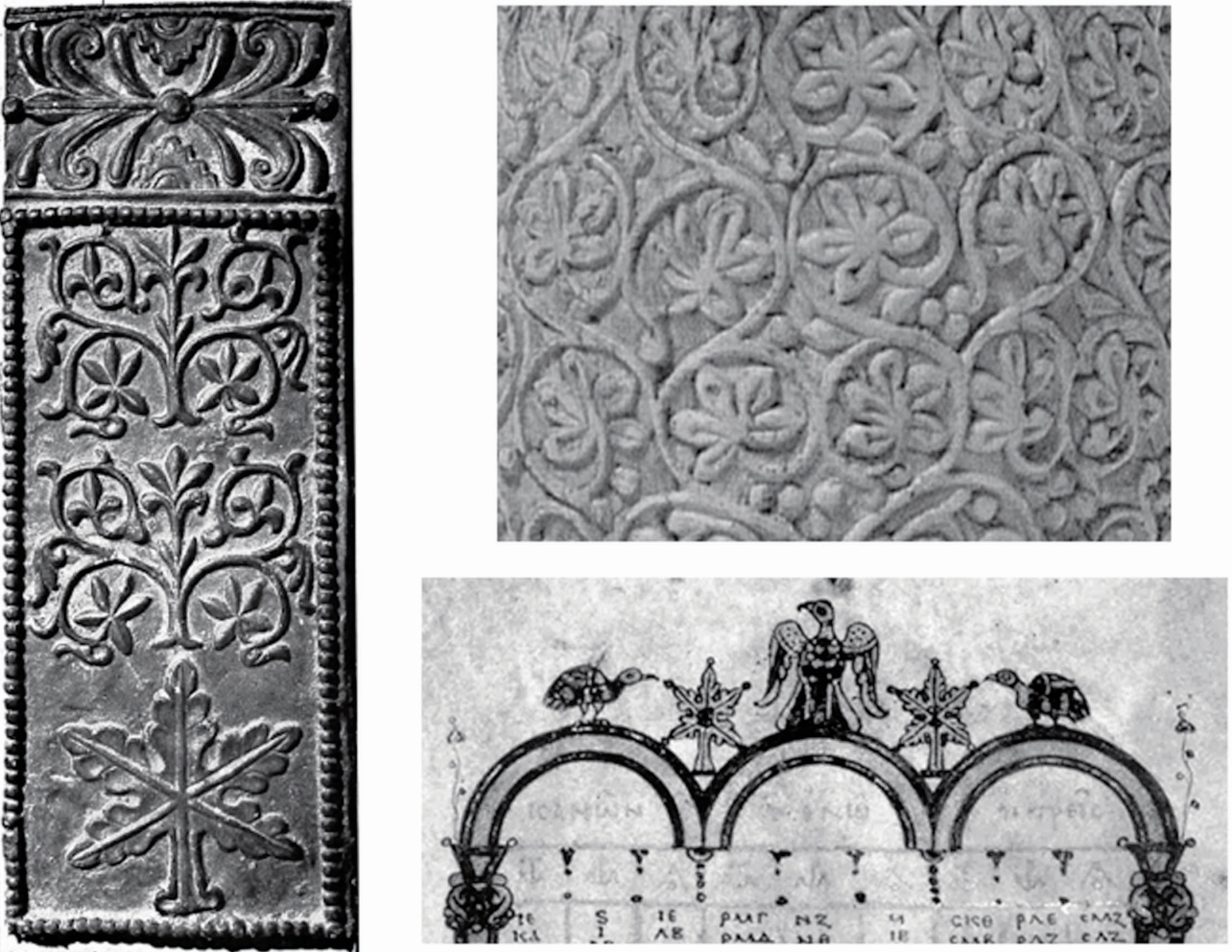

Fig. 1. a) Istanbul, Ayasofya Müzesi (St. Sophia), South-Vestibule, Details of the Bronze Door (photo S. Pedone); b) Berlin, Detail of the Pyxis with vine scroll ( $7^{\text {th }}-8^{\text {th }}$ Century); c) Venice, Marciana Library, Marc. Gr. I, 18, f. 2 v, particular of decoration.

progeny, in accordance with an artistic and epigraphic rhetoric well rooted in the Graeco-Roman tradition $[27 ; 40]$. A similar project inspired the works Theophilos undertook in the area of the Great Palace, between the Hippodrome and the sea line; terracing, public buildings and private constructions for the emperor himself and his family, with abundant use of ancient and precious materials, like marble and gold, tangible signs of an ancient power $[8 ; 15 ; 19 ; 26]$.

However, we have to acknowledge that modern historiography has emphasized above all other aspects, or the other face, so to speak, of the artistic patronage of Theophilos, that is to say his openness toward eastern culture and taste. In this context is particularly important the role of the so-called Bryas Palace, built on the Asiatic shores of Constantinople, in "imitation" of the famous Abbasid palaces, as the sources record [2; 24]. We read in Theophanes Continuatus that John the Grammarian, the emperor's tutor, astonished before the beauty of the Islamic buildings during a diplomatic mission in Baghdad in 831, was first who encouraged Theophilus to adopt that model $[8 ; 16 ; 17]$.The suggestion was accepted, but the real application of the model actually occurred far off from the official residence of the court, and while the appearance and the decoration of the Bryas Palace were probably somehow "exotic", the complex included, not surprisingly, two buildings consecrated to the Virgin Mary and 
the Archangel Michael. The forms of the original structure are synthetically sketched in the illumination of Skylitzes (Skilitzes Matritensis, Madrid, Biblioteca Nacional, Cod. Vitr. 26-2, fol. 48a) in which there is depicted a construction with three pointed domes and decorated by a dense non-iconic ornamentation with geometric and floral patterns [38]. Two little crosses on the domes make recognizable the sacred buildings commissioned by Theophilos. Since the last century the researches of archaeologists have hypothetically located the remains of the complex in the Asiatic suburb of Küçükyali, partly because of the analogy between some Abbasid palace architectures [14] and the big surrounding wall with the ample central rectangular space, now definitively identified with the substructions of a cistern. The several surveys of Alessandra Ricci and the finding of a lot of sculptural and floor fragments suggest now a new identification with the ruins of the monastery of Satyros [32], as also a later illuminated depiction of the monastery itself in the Menologion of Basil II would prove (Menologio di Basilio II, Biblioteca Apostolica Vaticana, Vat. Gr. 1613, p. 134). All in all, the construction of the Bryas Palace represented, in my opinion, an "instrumental" opportunity, a choice of taste from outside reshaped by the functional needs of Byzantine culture, as well as a confident concession to the aesthetic preferences of the mentor John the Grammarian.

However, if we come back to the capital, in particular to the Megale Ekklesia of Hagia Sophia, we can see another face of the official patronage and the aesthetic ideology of Theophilos, a face with very different features. I want to focus on the works he ordered to make on one of the many bronze doors of the church, to be more precise on the only spolia door often identified with the "Beautiful Door", also known through the sources (Fig. 1a, Ill. 45).

This is a real Classic "relic", today mounted in the doorway giving access to the so-called southern vestibule, in which the famous lunette mosaic with the emperors Constantine and Justinian was found and through which you can enter the narthex and the very heart of the building [39]. An important passage point for the visitors of the monument that however makes almost "transparent" the door itself [22; 23].

Unlike the other bronze doors still in situ, stylistically homogeneous and dating back to the Justinianic phase of the construction [18], our door is, on the contrary, an unicum, as a re-used Classic work, a Greek or Roman great double door of unknown provenance $[1 ; 3 ; 4$; $5 ; 6 ; 7 ; 12 ; 35 ; 36]$. The original structure was enlarged in height and width with the purpose of re-contextualizing and re-semantizing it in a different space, as a symbolic access to the starting point of the imperial liturgies. The door is documented only in late sources, and in particular it is mentioned several times in the Book of Ceremonies [13]. Its modern location was recorded by sketches and drawings of travellers during the $19^{\text {th }}$ century - as that by Charles Texier (1830s) or the engraving published in the volume devoted to the antiquities of Constantinople by Salzenberg (1854) - but also through many photographs of the end of the century [30].

Unfortunately, there is some uncertainty about the original position of the door and about the date of its positioning into the Hagia Sophia, also considering the lack of information about the date of construction of the vestibule and the disposition of the floor, which was probably reworked several times, with the resulting raising of the original level, which occurred one more time on the occasion of the restoration carried out by Gaspare and Giuseppe Fossati by the half of the $19^{\text {th }}$ century [30]. At that time the open valves of the door were still 
partly recessed into the floor, so that it was impossible to move the leaves, and also the sketches we have just seen depicted only the visible portion.

Only in 1963 the researchers of "Istituto Centrale per il Restauro" of Rome (the national institute for the restoration of artworks) brought to light the lower part of the door (about $50 \mathrm{~cm}$ high), creating a kind of niche (or a trench) in the floor which makes it visible, established the original height of the floor and discovered the early doorstep $[3 ; 4 ; 5 ; 6 ; 7]$. The pieces were in a poor condition, because of the weakening of the wood structure, the detachment of the bronze foils and the loss of some applied decorative elements. The restoration works, on both structure and decoration, were carried out in two steps. In 1963 the door leafs were unhinged, consolidated and cleaned; in a second stage, ten years later, the lost parts were restored and the door settled again upon its hinges. But, in the meantime the inscription with the name of Michael (the son of Theophilos) and the broad plate with rinceaux (applied in the $9^{\text {th }}$ century on the upper part of the right leaf) were stolen [5].

In fact, the door is constituted by a wooden structure, an ancient spoil (here highlighted in red) made up of precious wood of Lebanon cedar, and a bronze covering with a broad perimetral studded frame, four lesser horizontal panels and other four greater vertical ones, decorated with magnificent Classic borders made of frames with swastikas, acanthus leaves, rinceaux, vines with grapes, rows with lesbian kyma and little pearls dividing different orders of the frame. The exquisite execution of the decoration and the accuracy of the assembly of all the parts are particularly appreciable in the masterly cut of the corners, in the meticulous juxtaposition of the rows, in the concealment of the nails fixing the metal foils under the studs or the "invisible" insertion of them on the blooms of the acanthus.

The style reveals the ancient origin of the work, and the most compelling comparisons are to be made not so much with other bronze works but with Greek and Roman marble decorations, especially those ones inspired by Hellenistic style (Fig. 1a, Ill. 45), like the mosaic borders of the floor in the peristyle of the Great Palace of Constantinople or the grape leaves sculpted on the front of the ambo now held in the Archaeological Museum of Athens, both dated to the $6^{\text {th }}$ century.

Surely, in the Hagia Sophia there were several precious spoils reminding of the first construction of the church and its later rebuilding. Classic spoliae brought to Constantinople from every region of the empire to decorate the most important temple of the capital: columns, bases, fine marbles, liturgical vases and so on were the Classic endowment of the Megale Ekklesia. Nonetheless, the famous ekphraseis are silent about the "Beautiful Door", which is documented only later in the Book of Ceremonies - as we have already noted where a "door of the Horologion" is mentioned as located in the doorway which gave access to the narthex from outside, as nowadays $[6 ; 13]$. Thus, it is likely that the placing of the door and its reworking occurred in a post-justinianic age or, more precisely, according to Leslie Brubaker, under the rein of Theophilos, who not only decorated the doors with eight monograms damascened in silver, but also enlarged the ornamentation of the leaves to adapt the door to the width of the vestibule [8; 9]. The added outer borders interpret the Classic style of the ancient model imitating the same floral forms, but in fact making use of a rich repertoire well assimilated by the artistic Byzantine vocabulary from $6^{\text {th }}$ to $10^{\text {th }}$ century (Ill. 2-3). 
The vestibule was the entrance reserved to the emperor, here he took off the crown, met the Patriarch and entered with him in the narthex and then in the church, through the imperial doorway. This was therefore a symbolic place in which political and religious powers joined up in a minutely defined liturgical ceremonial [13]. Although we don't know the date of the vestibule construction it is possible to suppose that the southern access underwent some changes on the occasion of the works begun in the near baptistery in 813 . The little courtyard, which now is the resulting space between the south-western side of the building, the staircase to the southern gallery and the baptistery, is situated at a lower level which is probably to be connected with the original height of the floor of our door.

The special interest of Theophilos in the significance of the door is revealed by the insertion of the eight monograms in the upper and lower portions of the four major panels (two for each panel) in which the inscriptions originally read, in the upper part from left to right, "Lord help the ruler Theophilos" and "Mother of God help the empress Theodora", in the lower part, "Christ help the patriarch John [the Grammarian]" and the date, "the year from creation of the world 6347, indiction 2" (that is to say the year 838/9) [8; 25; 36]. The exact mention of the date could be an evidence that the door was located in that very year. Thanks to the damascening, now only partially visible, the names of the emperor and the Patriarch and the date of the inscription must have stood out conspicuously.

However, it has already been observed that two monograms were modified and the marks of scraping off the previous letters are still discernible. The alteration has substantially changed the meaning and the "message" of the inscription, erasing the Patriarch's name and replacing it with the name of emperor's first born. The date was modified as well and changed for 840/841. Two plates with the name of "Theophilos" and "Michael, the victorious" were also added to crown the upper part of the door leaves. The reasons for such a change were much debated in the past, and different hypothesis were suggested, from the disfavour the Patriarch fell into, to - more simply - the birth of Michael III (even if the exact birth date remains uncertain) [25]. Indeed, it is plausible that the birth of the heir must have had a stronger weight on the public dynastic strategies of Theophilos than his relations with the Patriarch, so that the "family reasons", that is "reasons of State", were eventually accorded pre-eminence over the symbolic sharing of religious power.

Thus, Theophilos' intentions were not so much to simply show or restore an ancient, precious relic, but to restate and literally "subscribe" to the visual and cultural living connection with the symbolic power of the Classic ianua. The re-semantization of such an "authoritative" piece of Roman art, through the "superimposition" of emperor's name and his dynasty, was an act of appropriation as well as of ideological continuity with the ancient imperial dignity [20], a gesture aiming at ratifying the endurance of both political and religious authority. The "Beautiful Doors" thus kept open the passage from past to future, something like a visible gate of time in a real rite of passage, across one of the most highly symbolic thresholds for Byzantine imagery of sacred power.

Title. The Emperor Teophilos (829-842). Between Classicism and Exoticism.

Author. Silvia Pedone - Ph. D. Sapienza Università di Roma, Piazzale Aldo Moro, 5, 00186, Roma, Italy. silvia.pedone@uniroma1.it; silvia.pedone@gmail.com 
Abstract. The topic which the present paper discusses concerns the art historical (and historiographic) problem of the transmission and reception of ancient models and spoliae during the reign of Theophilos, in a particularly difficult moment, between the Iconoclastic age and the Macedonian one. In the millenary history of Byzantium, the Macedonian period has been seen as the most favourable to a rebirth of Classical antiquity, as it was shown and ideologically attested by artistic display.

However, the preceding phase of the affirmation of the Macedonian dynasty has been rather underestimated, and specially the very attitudes of the emperor Theophilos toward art, which are somewhat more complex from an art-historical point of view. Indeed, in the Byzantine art of the period, at least in Constantinople, it is possible to discern a transition from an experimentation and appropriation of exotic features, as some stylistic elements of Islamic art, to a programmatic rebirth of a kind of "classicism" aiming at strengthening the continuity of political power. Thus, besides a taste for experimentation, we find nonetheless an opposite polarity, so far not sufficiently explored, open to a more instrumental or ideological visual strategy, through the re-semantization of Classical art forms because of their "authoritative" association with imperial dignity. In such a perspective, an interesting case is that of the Roman door of Hagia Sophia in Constantinople, the so-called "Beautiful Door", on which Theophilos placed his own monograms to ratify the endurance of both political and religious authority, on a highly symbolic threshold for Byzantine imagery of power.

Keywords: emperor Theophilos; Byzantine Empire; bronze door; St. Sophia Constantinople; classicism; exoticism; south-west vestibule; Byzantine art.

Название статьи. Император Феофил (829-842) между классицизмом и экзотикой.

Сведения об авторе. Педоне Сильвия - Ph. D., доцент. Римский университет Ла Сапиенца, Piazzale Aldo Moro 5, 00186 Рим, Италия. silvia.pedone@uniroma1.it

Аннотация. Тема статьи предполагает обсуждение искусствоведческих и историографических вопросов, связанных с использованием и восприятием античных образцов и фрагментов в империи Феофила в исключительно сложное время между иконоборческим и македонским периодами. В тысячелетней истории Византии македонский период считается наиболее благоприятным для возрождения классической древности, что идеологически подтверждается и о чем наглядно свидетельствуют произведения искусства.

Тем не менее этап, предшествующий утверждению македонской династии, недостаточно разработан именно в отношении взглядов императора Феофила на искусство, причем их осмысление представляет для искусствоведов известную сложность. Действительно, в византийском искусстве этого времени, по крайней мере в Константинополе, прослеживается отход от экспериментов с применением экзотической художественной стилистики, присущей, например, искусству ислама, в пользу программного возрождения своего рода «классицизма» для обоснования идеи непрерывной преемственности политической власти. Таким образом, наряду с тягой к эксперименту обнаруживается и противоположная, до сих пор слабо изученная тенденция внедрения более идеологически действенной наглядной стратегии, предполагающей переосмысление художественных форм античного искусства в связи с более весомым их «авторитетом» касательно представлений об императорском достоинстве. В этом смысле особый интерес представляет античная дверь южного вестибюля собора Святой Софии, так называемая «Роскошная дверь», на которой Феофил запечатлел свои монограммы в подтверждение долговечности политических и религиозных полномочий, избрав это место как высоко символичное для образной системы византийской власти.

Ключевые слова: император Феофил; Византийская империя; бронзовые врата; Святая София Константинопольская; классицизм; экзотика; южный вестибюль; византийское искусство.

\section{References}

1. Antoniades A. M. Ekfrasis tis Agias Sophias, 3 vols. Athenai, 1907-1909 (in Greek).

2. Bekker I. (ed.). Theophanes Continuatus. Bonn, Weber Publ., 1838. 951 p. (in Greek and in German).

3. Bertelli C. Le porte del VI secolo in Santa Sofia a Costantinopoli. Le porte di bronzo dallantichità al secolo XIII. Roma, Enciclopedia Italiana Treccani Publ., 1990, pp. 109-119 (in Italian).

4. Bertelli C. Notizia preliminare sul restauro di alcune porte di S. Sofia a Istanbul. Bollettino dell'Istituto Centrale del Restauro, 1958, 34-35, pp. 112-115 (in Italian). 
5. Borrelli Vlad L. La 'porta bella' di S. Sofia a Costantinopoli: un palinsesto. Le porte di bronzo dall'antichità al secolo XIII. Roma, Enciclopedia Italiana Treccani Publ., 1990, pp. 97-107 (in Italian).

6. Borrelli Vlad L. La porta dell'orologio di S. Sofia a Istanbul: riesame dopo un restauro. Annuario della Scuola Archeologica Italiana di Atene e delle Missioni Italiane in Oriente, 1979-1980, no. 57-58, pp. 375-419 (in Italian).

7. Borrelli Vlad L. Notiziario, Attività dell'Istituto all'estero. Bollettino dell'Istituto Centrale del Restauro, 1957, no. 31-31, pp. 182-187 (in Italian).

8. Brubaker L. Inventing Byzantine Iconoclasm. London, Bristol Classical Press Publ., 2012. 160 p.

9. Brubaker L. Vision and Meaning in Ninth-Century Byzantium: Image as Exegesis in the Homilies of Gregory of Nazianzus. Cambridge, Cambridge University Press Publ., 1999. 489 p.

10. Codoner J. S. The Emperor Theophilos and the East, 829-842: Court and Frontier in Byzantium During the Last Phase of Iconoclasm. Farnham, Ashgate Publ., 2014. 530 p.

11. Diehl Ch. La légende de l'Empereur Théophile. Seminarium Kondakovianum. Recueil d'Études. Archéologie. Histoire de l'art. Études byzantines, 1931, vol. IV, pp. 34-37 (in French).

12. Dirimtekin F. The Bronze Doors of Saint Sophia. Ayasofya Müzesi Yillı̆̆ , 1961, no. 3, pp. 42-46.

13. Ebersolt J. Sainte Sophie de Constantinople. Étude de topographie d’après les cerémonies. Paris, E. Leroux Publ., 1910 (in French).

14. Eyce S. Contributions à l'histoire de l'art byzantin. Quatre édifices inédits ou mal connus. 1. Les substructions d'un palais (?) à Küçükyali près d'Istanbul. Cahiers archéologiques. Fin de l'antiquité et du moyen age, 1959, no. 10, pp. 245-250 (in French).

15. Featherstone J. M. Luxury in the Palace: the Buildings of Theophilus. İstanbul Araștırmaları Y1llığ1 Publ., 2013, no. 2, pp. 33-40.

16. Gero S. John the Grammarian, the last iconoclast patriarch of Constantinople: the man and the legend. Byzantion, 1977, no. 3-4, pp. 25-35.

17. Griffith H. Euthychius of Alexandria on the Emperor Theophilus and Iconoclasm in Byzantium: A Tenth Century Moment in Christian Apologetics in Arabic. Byzantion, 1982, no. 52, pp. 154-190.

18. Guiglia A.; Barsanti C. Le porte e gli arredi architettonici in bronzo della Santa Sofia di Costantinopoli. Le porte del Paradiso. Arte e tecnologia bizantina tra Italia e Mediterraneo. Roma, Campisano Editore Publ., 2009, pp. 81-123 (in Italian).

19. Kostenec J. The Heart of the Empire: The Great Palace of the Byzantine Emperors Reconsidered. Secular Buildings and the Archaeology of the Everyday Life in the Byzantine Empire. Oxford, Oxbow Publ., 2004, pp. 4-36.

20. Koutrakou N. C. La propagande impériale byzantine. Persuasion et réaction (VIII ${ }^{e}-X^{e}$ siècle). Athens, Université nationale d'Athènes, Faculté des lettres Publ., 1994 (1996). 459 p. (in French).

21. Lethaby W. R.; Swainson H. The Church of Sancta Sophia Constantinople. A study of Byzantine Building. London-New York, Macmillan \& Co. Publ., - 1894. 327 p.

22. Mainstone R. Hagia Sophia. Architecture, Structure and Liturgy of Justinian's Great Church. London, Thames \& Hudson Publ. - 1988. 288 p.

23. Mango C. Archittetura bizantina. Milano, Electa Publ., 1974, pp. 194-196 (in Italian).

24. Mango C. The Art of the Byzantine Empire 312-1453. Source and Documents. Englewood Cliffs, N. J., Prentice-Hall Publ., 1972. 272 p.

25. Mango C. When was Michael III Born? Dumbarton Oaks Papers, 1967, no. 21, pp. 253-258.

26. Markopoulos A. The rehabilitation of the Emperor Theophilos. Dead or Alive: Byzantium in the Ninth Century. Aldershot, Ashgate Publ., 1998, pp. 37-49.

27. Müller-Wiener W. Bildlexikon zur Topographie Istanbuls: Byzantion -Konstantinupolis - Istanbul bis zum Beginn des 17. Jahrhunderts Tübingen, Wasmuth Publ., 1977 (in German). 534 p.

28. Mullett M.; Scott R. (eds.). Byzantium and the Classical Tradition. Birmingham, Centre for Byzantine Studies, University of Birmingham Publ., 1981. 250 p.

29. Nikolaou K. Oi gynaikes sto bio kai tà erga tou Teophilou. Simmeikta 9/2. Papers in Memory of D. A. Zakythinos, 1994, pp.137-151 (in Greek).

30. Pedone S. "Souvenirs d'une grandeur qui ne s'efface pas". La Santa Sofia di Giustiniano nei disegni di Charles Texier. Vie per Bisanzio, VIII Congresso Nazionale dell'Associazione Italiana di Studi Bizantini. Bari, Edizionipagina Publ., pp. 941-964 (in French).

31. Pedone S. Contagi bizantini. Fortune e sfortune del modello 'greco' nell'arte italiana. Cipro e l'Italia al tempo di Bisanzio. L'Icona grande di San Nicola tis Stegis del XIII restaurata a Roma, I. Nicosia, F1ère Édition Publ., 2015, pp. 38-51 (in Italian). 
32. Ricci A. The Road from Baghdad to Byzantium and the case of the Bryas Palace in Istanbul. Dead or Alive: Byzantium in the Ninth Century. Aldershot, Ashgate Publ., 1998, pp. 131-149.

33. Rosser J. Theophilos (829-842). Popular Sovereign. Hated Persecutor. Byzantiaka, 1983, no. 3, pp. $37-56$.

34. Schneider A. M. Die Grabung in Westhof der Sophienkirche zu Istanbul. Istanbuler Forschungen, no. 12. Berlin, Zweigstelle Istanbul des Archäologischen Instituts des Deutschen Reiches Publ., 1941. 45 p. (in German).

35. Strube C. Die westliche Eingangseite der Kirchen von Konstantinopel in justianischer Zeit. Wiesbaden, Harrassowitz Publ., 1973. 180, (62) p. (in German).

36. Swift E. H. The Bronze Doors of the Gate of Horologium at Hagia Sophia. Art Bulletin, 1937, 19, pp. 137-147.

37. Treadgold W. The Byzantine Revival, 780-842. Stanford, Stanford University Press, 1988. xviii, 504 p.

38. Tsamakda V. The illustrated Chronicle of Ioannes Skylitzes in Madrid. Leiden, Alexandros Press, 2002. $436 \mathrm{p}$.

39. Underwood P. A. Notes on the Work of the Byzantine Institute in Istanbul: 1957-1958. Dumbarton Oaks Papers, 1960, no. 14, pp. 205-222.

40. Van Millingen A. Byzantine Constantinople The Walls of the City and Adjoining Historical Sites. London, J. Murray Publ., 1899. 488 p.

41. Walker A. The Emperor and the World. Exotic Elements and Imaging of Middle Byzantine Imperial Power, Ninth to Thirteenth Centuries C.E. Cambridge, Cambridge University Press Publ., 2012. 